\title{
Commercial Bank Efficiency Evaluation in Consideration of the Undesirable Output and Its Link with Stakeholders Relationship: An Application of China's Commercial Banks
}

\author{
Jianyue Ji and Yanxia Wang \\ School of Economics, Ocean University of China, No. 238 Songling Road, Laoshan District, Qingdao 266100, China \\ Correspondence should be addressed to Jianyue Ji; jijianyue@163.com
}

Received 27 December 2013; Revised 5 March 2014; Accepted 7 April 2014; Published 30 April 2014

Academic Editor: Jianping Li

Copyright (c) $2014 \mathrm{~J}$. Ji and Y. Wang. This is an open access article distributed under the Creative Commons Attribution License, which permits unrestricted use, distribution, and reproduction in any medium, provided the original work is properly cited.

Based on the modern contract theory, expectancy theory, and stakeholder theory, this paper analyzes how stakeholders relationship influences the efficiency of commercial banks and finds that the efficiency is a function of stakeholders relationship. A DEA model with Seiford's linear transformation function is developed to evaluate the efficiency in consideration of the undesirable output. The panel Tobit model is established to conduct empirical research with data of 14 Chinese commercial banks from 2004 to 2012 . The study finds that except for business customer relation, stakeholder relationship is the key variable that influences comprehensive efficiency of commercial banks.

\section{Introduction}

With economic globalization, the banking sector plays a more and more important role in the economy both nationally and worldwide. The efficiency of a commercial bank affects both its competitiveness and the role it plays in economic development. Therefore, how to improve the efficiency of commercial banks has always been the hot topic for academics.

With respect to evaluation research on commercial bank efficiency, most scholars measure efficiency with DEA method because it does not need production function, while they differ in choosing output indicators. For example, Drake and Hall [1] and Das and Ghosh [2] took loan, investment, and other incomes to measure the commercial bank efficiency in Japan and India, respectively. Avkiran took loan, securities, bank deposits except deposits in the central bank, and non-interest income as the output indicators [3]. Wu et al. chose loan and operating income to carry on efficiency evaluation on Canada banks [4]. Hsiao et al. selected loan, investment, commission, and handling charge to conduct efficiency evaluation on 24 banks in Taiwan [5]. Luo et al. chose other assets, cash, and deposits in central bank, customer margin, and equity as the output indicators [6].
Wang selected interest income and non-interest income to conduct efficiency evaluation on Macau banks from 2006 to 2010 [7]. However, only a few scholars studied the undesirable output, such as Cui et al. [8]. In the process of commercial bank operation, non-performing loans and other undesirable output are inevitable. The efficiency evaluation without undesirable output affects the accuracy of the measurement and does not conform to the actual situation.

Many scholars have also studied the influence factors of commercial bank efficiency. Allen et al. studied the effect of branch number on the efficiency of American banks and found out that their inefficiency was directly related to the excessiveness of branches [9]. Drake et al. studied the impact of macroeconomic and regulatory on the efficiency of Hong Kong banks [10]. Battaglia et al. studied the influence of population density, business profit, per capita GDP, the number of ATM and POS machine, and other economic environment conditions on the efficiency of cooperative banks [11]. Hermes and Nhung studied the impact of financial liberalization on the efficiency of banks in Latin America and Asia from 1991 to 2000 and found that the financial liberalization had a significant positive correlation with bank efficiency [12]. Tanna et al. selected 17 US banks from 2001 
to 2006 to study the effect of board structure and found that the board size positively affected the bank efficiency, while its structure had a more significant positive effect [13]. Sun et al. studied the impact of strategic investor on the efficiency of Chinese commercial banks under the background of regional economy, and results showed that the introduction of strategic investors can improve their efficiency [14].

None of the above researches studied the bank efficiency from the perspective of stakeholders. Based on the stakeholder theory [15], modern contract theory, and expectancy theory, we believe in that stakeholders affect the efficiency of commercial banks. This paper will analyze the efficiency of commercial banks from the perspective of stakeholders.

The paper is organized as follows. Section 2 mainly introduces the method of commercial bank efficiency evaluation with undesirable output and establishes the model of stakeholders relationship and bank efficiency. Section 3 conducts an empirical analysis. Section 4 draws the conclusion.

\section{Basic Models}

2.1. Commercial Bank Efficiency Evaluation Model with Undesirable Output. Many scholars have made attempts to use DEA to evaluate the efficiency with undesirable output. Hailu and Veeman directly took the undesirable output variables as input variables [16]. Scheel got the efficiency value through classic DEA model by transforming the undesirable output into desirable one by its reciprocal [17]. These methods did not conform to the fact and resulted in inaccuracy for efficiency evaluation. Some others used SBM model to evaluate commercial bank efficiency solving above problems by putting slack variable into the objective function, while being difficult to understand and explain the specific economic implications of $\rho$ [18]. Based on Seiford's method turning undesirable output into desirable one by linear transformation function, this paper conducts DEA model to evaluate the efficiency [19].

Suppose that there are $k$ kinds of decision making units, $m$ kinds of input, $n$ kinds of desirable output, and $l$ kinds of undesirable output. The corresponding vector matrix form is as follows:

$$
\begin{aligned}
X & =\left[x_{1}, \ldots, x_{k}\right] \in R^{m \times k}, \\
Y^{q} & =\left[y_{1}^{q}, \ldots, y_{k}^{q}\right] \in R^{n \times k}, \\
Y^{f} & =\left[y_{1}^{f}, \ldots, y_{k}^{f}\right] \in R^{l \times k},
\end{aligned}
$$

where $R$ is the real number set, and $X>0, Y^{q}>0, Y^{f}>$ 0 . Under the condition of constant returns to scale, the production function of commercial banks can be represented as

$$
P=\left\{\left(x, y^{q}, y^{f}\right) \mid x \geq X \lambda, y^{q} \leq Y^{q} \lambda, y^{f} \geq Y^{f} \lambda, \lambda \geq 0\right\},
$$

where $P$ represents the output sets of commercial banks, and $X, Y^{q}, Y^{f}$ represent input vector, desirable output vector, and the undesirable output vector, respectively. Undesirable output $\left(y^{f}\right)$ is converted into desirable output $\left(y^{f^{\prime}}\right)$ by the function of $y^{f^{\prime}}=v-y^{f}$, where $v$ is big enough. The DEA model is built as follows:

$$
\begin{array}{ll}
\min & \theta_{0} \\
\text { st } \quad & \sum_{j=1}^{k} \lambda_{j} x_{i j} \leq \theta_{0} x_{i 0}, \quad i=1,2, \ldots, m \\
& \sum_{j=1}^{k} \lambda_{j} y_{r j}^{q} \geq y_{r 0}, \quad r=1,2, \ldots, n \\
& \sum_{j=1}^{k} \lambda_{j} y_{t j}^{f^{\prime}} \geq y_{t 0}^{f^{\prime}}, \quad t=1,2, \ldots, l \\
& \sum_{j=1}^{k} \lambda_{j}=1 \\
& \lambda_{j} \geq 0, \quad \theta \leq 1, \quad j=1,2, \ldots, k,
\end{array}
$$

where $\theta_{0}$ is the efficiency of $D M U_{j 0}, \lambda$ is weight vector, and $x_{i j}, y_{r j}^{q}, y_{t j}^{f}$ are the observed input, desirable output, and undesirable output values, respectively.

\subsection{The Analysis Model of Commercial Bank Efficiency with Stakeholder Relationship}

2.2.1. Production Function of Commercial Banks. According to the modern contract theory, an organization is the combination of a series of contracts reached by different stakeholders. Different stakeholders meet their own interests through executing the contract, which means output is realized by stakeholder input [20]. So we can get the production function as follows:

$$
Y=f(X)
$$

where $Y=\left(Y^{n}, Y^{l}\right)$ represents the various outputs, $Y^{n}$ is desirable output, and $Y^{l}$ is the undesirable output. $X=$ $\left(X_{1}, X_{2}, \ldots, X_{m}\right)$ represents the corresponding input of each stakeholder to the banks. The function signifies the bank output is determined by corresponding resources input from various stakeholders.

2.2.2. Input Function of Commercial Banks. Expectancy theory [21] points out that worker always expect to meet certain needs and desire to achieve the goal set by enterprises through personal efforts. The higher rewards they earn from the enterprise, the more hardworking the employees will be. Besides employee input, commercial banks need the input of various stakeholders. So the resources put into banks by various stakeholders depend on their satisfaction degree of compensation getting from banks [22]. The stakeholder relationship is defined as the interdependence and mutual trust built by stakeholders and commercial banks during their long-term operation. The better the relation between the two, 
the more resources various stakeholders put into banks. And the function is as follows:

$$
X=h(S)
$$

where $X$ is the same as above, $S=\left(S_{1}, S_{2}, \ldots, S_{n}\right)$ signifies stakeholder relationship, and $S_{n}$ represents the $n$th stakeholder relationship. When $\partial X / \partial S>0$, it means that the better their relationship is, the more resources the stakeholders put into banks.

Combining formulas (4) and (5), the influence of stakeholder relationship on bank output by affecting the resource input of stakeholders can be demonstrated as

$$
Y=f(X)=f[h(S)]=Y(S) .
$$

Formula (6) means various stakeholders relationship can affect bank's output.

\subsubsection{Analysis of the Link between Commercial Bank Effi-} ciency and Stakeholders Relationship. According to Robbins definition, efficiency is the ratio of input to output, which mean under the condition of fixed input the more the output, the higher the efficiency. Combining the analysis of formulas (5) and (6), the efficiency of commercial banks can be represented by the ratio of output $(Y(S))$ to input $(X(S))$ :

$$
E=\frac{Y(S)}{X(S)}=E(S)
$$

According to formula (7), when the efficiency reaches its maximum, the following formula is established:

$$
\begin{aligned}
\frac{\partial E}{\partial S_{i}} & =\frac{\left(\partial Y / \partial S_{i}\right) \cdot X(S)-\left(d X_{i} / d S_{i}\right) \cdot Y(S)}{[X(S)]^{2}} \\
& =\frac{\left(d Y / d X_{i}\right) \cdot\left(d X_{i} / d S_{i}\right) \cdot X(S)-\left(d X_{i} / d S_{i}\right) \cdot Y(S)}{[X(S)]^{2}}=0 .
\end{aligned}
$$

Therefore, when $\left(d Y / d X_{i}\right) \cdot\left(d X_{i} / d S_{i}\right) \cdot X(S)=\left(d X_{i} / d S_{i}\right) \cdot Y(S)$, namely, $d Y / Y(S)=d X_{i} / X(S)$, the efficiency of commercial bank reaches its maximum. And when $d Y / Y(S)>d X_{i} / X(S)$, the output change rate brought about by stakeholder relationship is larger than the input one, improving stakeholder relationship can enhance the efficiency of commercial banks. When $d Y / Y(S)<d X_{i} / X(S)$, the input change rate is larger than the output one, improving stakeholder relationship can reduce the efficiency of commercial banks.

\subsubsection{Tobit Model of Link between Commercial Bank Efficiency} and Stakeholders Relationship. According to the above analysis, it is hypothesized that the commercial bank efficiency is the function of stakeholder relationship. As the evaluated efficiency values are between 0 and 1 , this paper conducts the limited dependent variable Tobit model. Tobit model with the maximum likelihood method averts the inaccuracy of least square method estimation [23], and Tobit model is established as follows:

$$
\begin{gathered}
E_{i}^{\prime}=a_{0}+\sum_{j=1}^{k} a_{j} S_{j i}+\sum_{s=1}^{m} b_{s} C_{s i}+\varepsilon_{i}, \\
E_{i}=E_{i}^{\prime} \quad \text { if } 0<E_{i}^{\prime} \leq 1, \\
E_{i}=0 \quad \text { if } E_{i}^{\prime}<0, \\
E_{i} \quad \text { if } E_{i}^{\prime}>1, \\
\varepsilon_{i} \sim N\left(0, \sigma^{2}\right),
\end{gathered}
$$

where $E_{i}^{\prime}$ is latent variables, $E_{i}$ is the actual efficiency value, $a_{0}$ is constant term, $a_{j}, b_{s}$ are regression coefficient to be estimated, $S_{i j}$ is independent variables which represents stakeholder relationship, and $C_{s i}$ is control variables.

\section{Empirical Study of the Link between Commercial Bank Efficiency and Stakeholder Relationship}

3.1. Sample Selection and Data Sources. The research object of this study is the commercial Banks in China. Considering the availability and representativeness of data, we used the data of 14 Chinese commercial banks from 2004 to 2012, including Industrial and Commercial Bank of China (ICBC), China Construction Bank (CCB), Bank of China (BOC), Agricultural Bank of China (ABC), Bank of Communications (BOCOM), China Citic Bank (CNCB), Huaxia Bank (HB), China Minsheng Bank (CMBC), China Everbright Bank (CEB), China Merchants Bank (CMB), Guangdong Development Bank (GDB), Ping An Bank (PAB), Shanghai Pudong Development Bank (SPDB), and China's Industrial Bank (CIB). The total assets of selected banks account for most of Chinese banks at the time of conducting the research, and these banks' businesses almost cover all the possible businesses of Chinese commercial banks. The selected samples are representative enough to reflect the overall efficiency of Chinese commercial banks. The data used in this paper are from "China Financial Yearbook" and the annual report of banks.

3.2. Input and Output Indicators. This paper selects the deposit, number of employees, and fixed assets as input indicators, and operating income and non-performing loans as output indicators. Taking non-performing loans as undesirable output can more accurately measure Chinese commercial banks efficiency. The input and output indicators are shown in Table 1.

3.3. Commercial Bank Efficiency Evaluation Based on DEA Model. Employing the DEA model, the bank efficiency values are shown in Table 2.

From Table 2, we can see that the efficiency values of Chinese commercial banks from 2004 to 2012 sustain a falling trend as a whole. The efficiency values of the stateowned commercial banks are generally lower than joint-stock 
TABLE 1: The descriptive statistics of input and output indicators.

\begin{tabular}{lccccc}
\hline Indicators & Deposit & Number of employees & Fixed assets & Operating income & Non-performing loans \\
\hline Average & 2718942.98 & 119052 & 31986.79 & 104885.81 & 60026.50 \\
Standard deviation & 3179215.66 & 155999.39 & 39634.34 & 145641.82 & 146698.25 \\
\hline
\end{tabular}

TABLE 2: China's commercial bank efficiency values.

\begin{tabular}{lllllllllccccc}
\hline Bank & 2004 & 2005 & 2006 & 2007 & 2008 & 2009 & 2010 & 2011 & 2012 & Average & Rank \\
\hline PAB & 1.000 & 1.000 & 0.901 & 1.000 & 0.879 & 0.993 & 0.688 & 0.666 & 0.698 & 0.869 & 1 \\
HB & 0.895 & 0.817 & 0.785 & 0.725 & 0.639 & 0.573 & 0.526 & 0.437 & 0.383 & 0.642 & 2 \\
GDB & 0.694 & 0.839 & 0.714 & 0.805 & 0.654 & 0.500 & 0.503 & 0.499 & 0.385 & 0.621 & 3 \\
CIB & 0.902 & 0.785 & 0.698 & 0.630 & 0.448 & 0.401 & 0.354 & 0.596 & 0.597 & 0.601 & 4 \\
SPDB & 1.000 & 0.870 & 0.604 & 0.539 & 0.472 & 0.389 & 0.368 & 0.412 & 0.435 & 0.565 & 5 \\
CMBC & 1.000 & 0.719 & 0.514 & 0.437 & 0.430 & 0.376 & 0.369 & 0.449 & 0.366 & 0.518 & 6 \\
CEB & 0.954 & 0.672 & 0.515 & 0.545 & 0.451 & 0.394 & 0.377 & 0.328 & 0.324 & 0.507 & 7 \\
CNCB & 0.643 & 0.580 & 0.559 & 0.516 & 0.408 & 0.364 & 0.323 & 0.361 & 0.349 & 0.456 \\
CMB & 0.362 & 0.363 & 0.353 & 0.332 & 0.273 & 0.242 & 0.260 & 0.291 & 0.296 & 0.308 \\
BOCOM & 0.207 & 0.210 & 0.190 & 0.193 & 0.187 & 0.158 & 1.000 & 0.181 & 0.175 & 0.278 & 9 \\
CCB & 0.125 & 0.120 & 0.117 & 0.141 & 0.149 & 0.127 & 0.135 & 0.144 & 0.137 & 0.133 \\
BOC & 0.119 & 0.116 & 0.118 & 0.136 & 0.142 & 0.111 & 0.114 & 0.154 & 0.119 & 0.125 \\
ICBC & 0.076 & 0.094 & 0.093 & 0.118 & 0.125 & 0.113 & 0.127 & 0.160 & 0.163 & 0.119 \\
ABC & 0.059 & 0.044 & 0.055 & 0.093 & 0.110 & 0.094 & 0.100 & 0.116 & 0.113 & 0.087 \\
\hline Average & 0.574 & 0.516 & 0.444 & 0.444 & 0.383 & 0.345 & 0.375 & 0.342 & 0.324 & 11 \\
\hline
\end{tabular}

ones. The efficiency value of Agricultural Bank of China is the lowest while that of Ping An Bank is the highest. The efficiency value of Ping An Bank keeps the efficient frontier for three years among the joint-stock commercial banks.

\subsection{Research of Influencing Factors of the Stakeholder Relationship to Commercial Bank Efficiency}

3.4.1. Stakeholder Relationship Indicators. This study selects the shareholders, employees, creditors, business customers, and regulators as five major stakeholders of commercial banks. Indicators are selected to represent stakeholder relationship as follows.

(a) Shareholder Relation. Shareholders are the most important stakeholders of commercial banks. Their main concern is the benefits they can obtain after putting into corresponding funds. Return on equity is selected here to measure the relationship between shareholders and the commercial banks. It is represented by the ratio of net profit to owner's equity. The higher the indicator value, the better the relationship between shareholders and commercial banks.

(b) Employee Relation. According to the expectancy theory, the higher payment staff obtain, the more hardworking the staff will be. With comprehensive consideration to the availability of data, the ratio of cash paid to and for employees to the total assets is selected here to represent the employee relation. The higher the indicator value, the better the relationship between employee and bank.

(c) Creditor Relation. Deposit is one of the major sources of bank funds. Creditors deposit money in banks and obtain interest and principal in due time. Their main focus is that the bank can pay their due principal and interest. The creditor relation is represented by interest expense ratio, which is calculated by the ratio of interest expense to total liabilities. The higher the ratio value, the better the relationship between creditors and banks.

(d) Business Customer Relation. Business customers here mainly refer to the customers who take out loans at banks except creditors on narrow sense. The ratio of interest income to disbursement of advances and loans is used here to represent the business customer relation. The lower the ratio, the less interest the banks charge borrowers. Therefore, borrowers are willing to take out loans and the relationship between business customers and banks becomes better.

(e) Regulator Relation. The index of capital adequacy ratio (CAR) is selected here to show the relationship between the banks and regulators. CAR is a ratio of bank capital to risk assets. It is the necessary capital ratio to guarantee the normal operation and development of banks. Regulators supervise CAR to test banks' ability to resist risks. The higher the index is, the better the relationship between regulators and banks become. 
TABLE 3: Definition of variables.

\begin{tabular}{lcll}
\hline Variables & Symbol & Description & Computational formula \\
\hline $\begin{array}{l}\text { Explained variable } \\
\quad \text { Efficiency }\end{array}$ & $E$ & Commercial bank efficiency & DEA evaluation \\
$\begin{array}{l}\text { Explanatory variable } \\
\text { Stakeholder relation }\end{array}$ & $S_{1}$ & Return on equity & \\
Employee relation & $S_{2}$ & Ratio of cash paid for employee & Cet profit/owner's equity \\
Creditor relation & $S_{3}$ & Interest expense rate & Interest expense/total liability \\
Business customer relation & $S_{4}$ & Interest income rate & - Interest income/loan offer and advance money \\
Regulator relation & $S_{5}$ & Capital adequacy ratio & Capital/risk assets \\
Control variable & & & \\
Bank scale & $C_{1}$ & Total assets & Total assets standardization \\
Ownership structure & $C_{2}$ & Ownership & Dummy variable \\
\hline
\end{tabular}

${ }^{1}$ As the business customer relation is a negative index, the negative value of interest income ratio is used here for the consistency of the follow-up measurement results and empirical analysis.

TABLE 4: Descriptive statistics of variables.

\begin{tabular}{|c|c|c|c|c|c|c|c|}
\hline Indicators & $S_{1}$ & $S_{2}$ & $S_{3}$ & $S_{4}$ & $S_{5}$ & $C_{1}$ & $C_{2}$ \\
\hline Average & 0.461042 & 0.213592 & 0.018063 & 0.948125 & 0.093588 & 0.000000 & 0.357143 \\
\hline Standard deviation & 3.338196 & 0.091067 & 0.005167 & 9.726405 & 0.026019 & 1.000000 & 0.481070 \\
\hline
\end{tabular}

In addition, bank size and ownership structure are regarded as control variables to explain the efficiency of commercial banks [24]. The ownership structure is dummy variable, which is 1 for the state-owned banks and 0 for others. Bank scale is signified by asset indicators with standardization of extreme-value of the total assets. Variables are shown in Table 3.

Table 4 shows the descriptive statistics of each variable.

3.4.2. Tobit Model Regression and Result Analysis. According to the above analysis, this paper takes bank efficiency as explained variables and the shareholder relation $\left(S_{1}\right)$, employee relation $\left(S_{2}\right)$, creditor relation $\left(S_{3}\right)$, business customer relation $\left(S_{4}\right)$, regulator relation $\left(S_{5}\right)$, as explanatory variables and the bank scale and ownership structure as control variables. The panel Tobit model is built as follows:

$$
\begin{aligned}
E_{i t}= & a_{0}+a_{1} S_{1 i t}+a_{2} S_{2 i t}+a_{3} S_{3 i t} \\
& +a_{4} S_{4 i t}+a_{5} S_{5 i t}+b_{1} C_{1 i t}+b_{2} C_{2 i t},
\end{aligned}
$$

where $E_{i t}$ is the efficiency value of the $i$ th bank in $t$ th year, $a_{0}$ is constant, $S_{1 i t}, S_{2 i t}, S_{3 i t}, S_{4 i t}$, and $S_{5 i t}$ mean the value of the five major stakeholders relationship of the $i$ th bank in $t$ th year, respectively, $C_{1 i t}$ and $C_{2 i t}$ mean the asset scale and ownership structure of the $i$ th bank in the $t$ th year, respectively, and $a_{1}$, $a_{2}, a_{3}, a_{4}, a_{5}, b_{1}$, and $b_{2}$ are all coefficients to be estimated.

According to the Tobit model, the regression results are shown in Table 5.

From Table 5, the log likelihood value is 38.72 and $P$ value is 0.000 , showing that Tobit model can well explain the link between stakeholders relationship and efficiency obtained by DEA. For the regression coefficients, we can find the following.
TABLE 5: Regression results.

\begin{tabular}{lccc}
\hline Variable & Coefficient & $T$ value & $P$ value \\
\hline$a_{0}$ & 0.9670761 & 10.26 & $0.000^{* * *}$ \\
$a_{1}$ & -0.0143655 & -3.03 & $0.003^{* * *}$ \\
$a_{2}$ & -0.8510089 & -3.06 & $0.003^{* * *}$ \\
$a_{3}$ & 10.48215 & 3.13 & $0.002^{* * *}$ \\
$a_{4}$ & 0.000122 & 0.08 & 0.936 \\
$a_{5}$ & -4.030018 & -4.91 & $0.000^{* * *}$ \\
$b_{1}$ & -0.008227 & -0.32 & 0.749 \\
$b_{2}$ & -0.3400626 & -4.55 & $0.000^{* * *}$ \\
Log likelihood & 38.72 & $P$ value & 0.000 \\
\hline
\end{tabular}

Note: ${ }^{* * *}$ indicates significance at $1 \%$ level (two-tailed).

(a) The shareholder relation cannot improve the efficiency of commercial banks and it is significant in statistics. Shareholder capital input change rate brought about by shareholder relation improvement is larger than output change rate, which reduces bank efficiency.

(b) Employee relation has negative correlation with the efficiency of commercial banks and it is significant under the level of 1\%. High wages does not improve the bank efficiency but reduced it instead. The output change rate brought about by employee salary increase is smaller than human capital change rate, which reduces bank efficiency.

(c) Creditor relation is beneficial to the bank efficiency, and it is significant under the confidence level of $1 \%$. This suggests that the output change rate brought about by creditor relation improvement is larger than the capital input change rate. Therefore, keeping a 
good relationship with creditors will promote the efficiency of banks.

(d) Business customer relation can improve the efficiency of banks, but it is not significant in statistics. The result is consistent with the facts. Given the diversity of repayment ways, time lag, and other reasons, bank efficiency is not sensitive to the business customer relation in the short term.

(e) Regulator relation is negatively related to the efficiency of commercial banks, and it is significant under $1 \%$ confidence level. The corresponding capital input change rate brought about by regulator relation improvement is larger than the output change rate, which is unfavorable to bank efficiency.

(f) In the aspect of control variables, the bank scale is negatively correlated with the efficiency of commercial banks. The result implies that China's commercial banks are in a state of diseconomies of scale, but it is not significant in statistics. The ownership structure is negatively related to the efficiency and it is significant under the confidence level of $1 \%$. It shows that the efficiency of other joint-stock commercial banks is higher than that of the state-owned commercial banks.

\section{Conclusion}

This paper analyzes the efficiency of commercial banks from the perspective of stakeholders. According to the analysis of production function and input function of commercial banks, it concludes that the stakeholder relationship has influences on both the output and input of commercial banks. Based on the analysis of formula (8), it proves that when the output change rate brought about by stakeholder relationship is larger than input one, the enhancement of stakeholder relationship can improve the efficiency of commercial banks. And when the input change rate brought about by stakeholder relationship is larger than output one, the enhancement of stakeholder relationship can reduce the efficiency of commercial banks. To summarize, stakeholder relationship is the key variable that influences comprehensive efficiency of commercial banks.

This paper incorporates undesirable output into the efficiency analysis of the commercial bank. A DEA model with Seiford's method of linear transformation function is developed to conduct efficiency evaluation. Based on the panel of Tobit model, this paper takes 14 commercial banks as sample and carries on the empirical research between bank efficiency and the stakeholder relationship. The results show that except for business customer relation, other stakeholders relationships have significant influence on the efficiency of commercial banks. Among them, shareholder relation, employee relation, and regulator relation have negative correlation with bank efficiency, while the creditor relation is positively correlated with bank efficiency.

\section{Conflict of Interests}

The authors declare that there is no conflict of interests regarding the publication of this paper.

\section{Acknowledgment}

The work is supported by National Science Foundation of China (Approval no. 71172099).

\section{References}

[1] L. Drake and M. J. B. Hall, "Efficiency in Japanese banking: an empirical analysis," Journal of Banking and Finance, vol. 27, no. 5, pp. 891-917, 2003.

[2] A. Das and S. Ghosh, "Financial deregulation and profit efficiency: a nonparametric analysis of Indian banks," Journal of Economics and Business, vol. 61, no. 6, pp. 509-528, 2009.

[3] N. K. Avkiran, "Developing foreign bank efficiency models for DEA grounded in finance theory," Socio-Economic Planning Sciences, vol. 40, no. 4, pp. 275-296, 2006.

[4] D. Wu, Z. Yang, and L. Liang, "Using DEA-neural network approach to evaluate branch efficiency of a large Canadian bank," Expert Systems with Applications, vol. 31, no. 1, pp. 108115, 2006.

[5] B. Hsiao, C.-C. Chern, Y.-H. Chiu, and C.-R. Chiu, "Using fuzzy super-efficiency slack-based measure data envelopment analysis to evaluate Taiwan's commercial bank efficiency," Expert Systems with Applications, vol. 38, no. 8, pp. 9147-9156, 2011.

[6] Y. Luo, G. Bi, and L. Liang, "Input/output indicator selection for DEA efficiency evaluation: an empirical study of Chinese commercial banks," Expert Systems with Applications, vol. 39, no. 1, pp. 1118-1123, 2012.

[7] X. Wang, "Analysis of evolution of banking efficiency of macao during 2006-2010 with DEA Method," Finance, vol. 2, no. 3, pp. 155-160, 2012.

[8] Q. Cui, Z. Zhao, and Q. Wang, "Study on the efficiency of Chinese commercial banks considering undesirable output," East China Economic Managemen, no. 5, pp. 78-82, 2012.

[9] N. B. Allen, H. L. John, and J. M. John, "The efficiency of bank branches," Journal of Monetary Economics, vol. 40, no. 1, pp. 141162, 1997.

[10] L. Drake, M. J. B. Hall, and R. Simper, “The impact of macroeconomic and regulatory factors on bank efficiency: a nonparametric analysis of Hong Kong's banking system," Journal of Banking and Finance, vol. 30, no. 5, pp. 1443-1466, 2006.

[11] F. Battaglia, V. Farina, F. Fiordelisi, and O. Ricci, "The efficiency of cooperative banks: the impact of environmental economic conditions," Applied Financial Economics, vol. 20, no. 17, pp. 1363-1376, 2010.

[12] N. Hermes and V. T. H. Nhung, "The impact of financial liberalization on bank efficiency: evidence from Latin America and Asia," Applied Economics, vol. 42, no. 26, pp. 3351-3365, 2010.

[13] S. Tanna, F. Pasiouras, and M. Nnadi, "The effect of Board Size and Composition on the Efficiency of UK Banks," International Journal of the Economics of Business, vol. 18, no. 3, pp. 441-462, 2011.

[14] J. Sun, K. Harimaya, and N. Yamori, "Regional economic development, strategic investors, and efficiency of Chinese city 
commercial banks," Journal of Banking \& Finance, no. 37, pp. 1602-1611, 2013.

[15] R. E. Freeman, Strategic Management: A Stakeholder Approach, Pitman, Boston, Mass, USA, 1984.

[16] A. Hailu and T. S. Veeman, "Non-parametric productivity analysis with undesirable outputs: an application to the Canadian pulp and paper industry," American Journal of Agricultural Economics, vol. 83, no. 3, pp. 605-616, 2001.

[17] H. Scheel, "Undesirable outputs in efficiency valuations," European Journal of Operational Research, vol. 132, no. 2, pp. 400410, 2001.

[18] Z. Tu and L. Liu, "Efficiency evaluation of industrial sectors in China accounting for the energy and environment factorsbased on provincial data by a SBM approach," Economic Review, no. 2, pp. 55-65, 2011.

[19] L. M. Seiford and J. Zhu, "Modeling undesirable factors in efficiency evaluation," European Journal of Operational Research, vol. 142, no. 1, pp. 16-20, 2002.

[20] A. N. Berger, D. Hancock, and D. B. Humphrey, "Bank efficiency derived from the profit function," Journal of Banking and Finance, vol. 17, no. 2-3, pp. 317-347, 1993.

[21] V. H. Vroom, Work and Motivation, John Wiley and Sons, New York, NY, USA, 1964.

[22] J. Ji, F. Yu, and C. Wang, "Stakeholder's relationship and financial performance of commercial bank-an empirical analysis based on the panel data of China's listed banks," Finance Forum, no. 12, pp. 64-72, 2012.

[23] J. Tobin, "Estimation of relationships for limited dependent variables," The Econometric Society, vol. 26, no. 1, pp. 24-36, 1958.

[24] L. Zheng and T. Cao, "An empirical analysis of China's commercial bank efficiency and its influencing factors," Finance Forum, no. 1, pp. 91-101, 2005. 


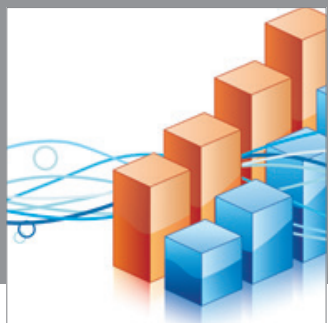

Advances in

Operations Research

mansans

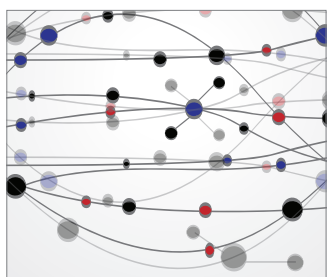

The Scientific World Journal
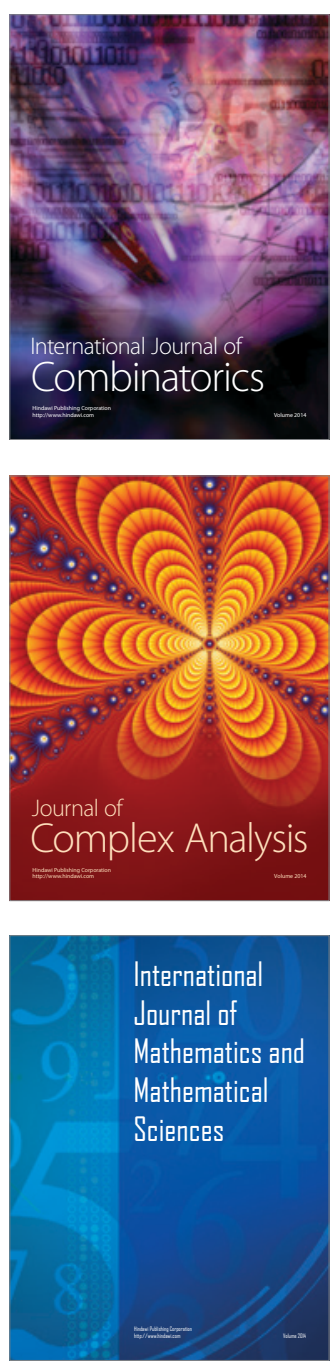
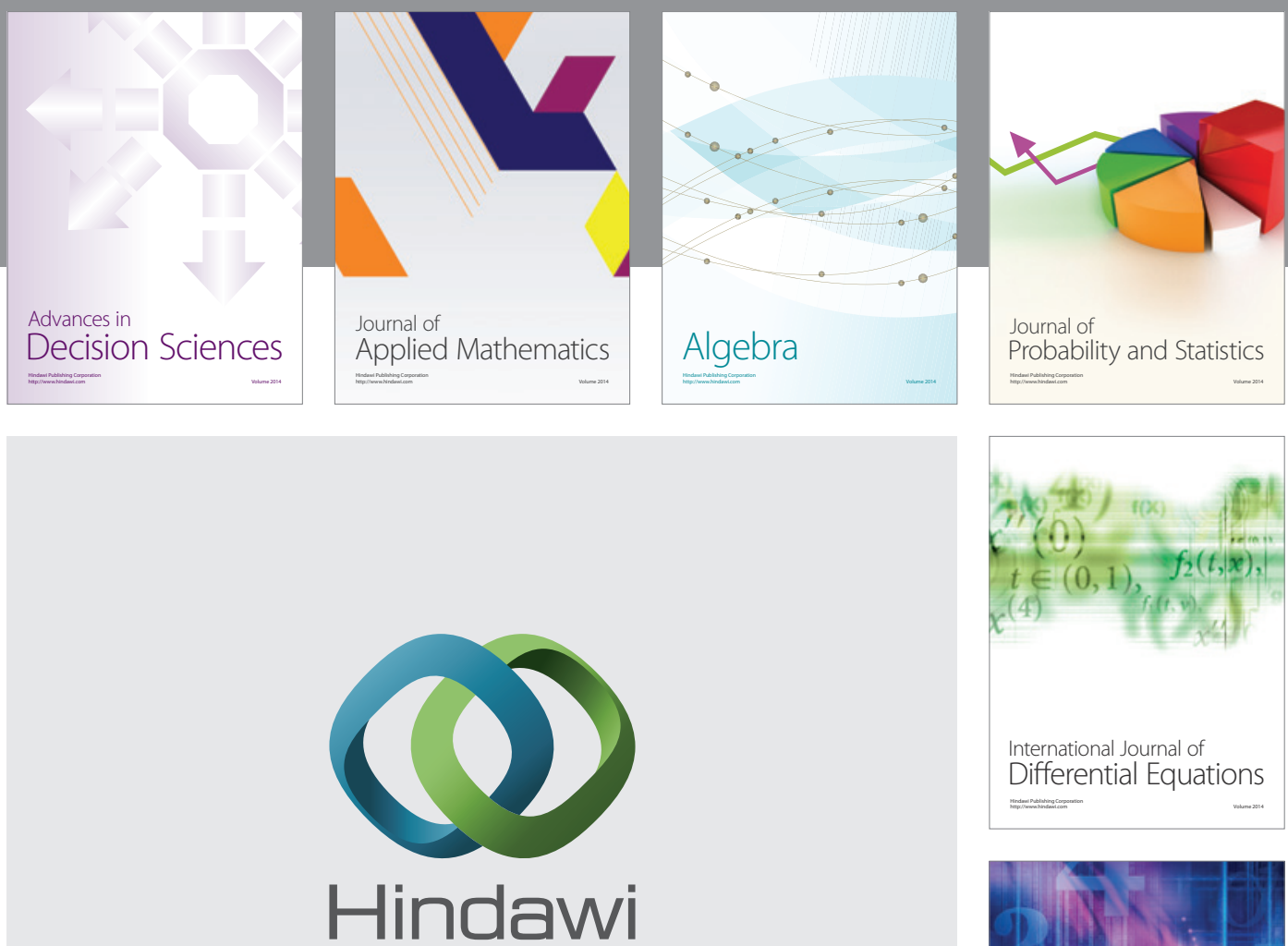

Submit your manuscripts at http://www.hindawi.com
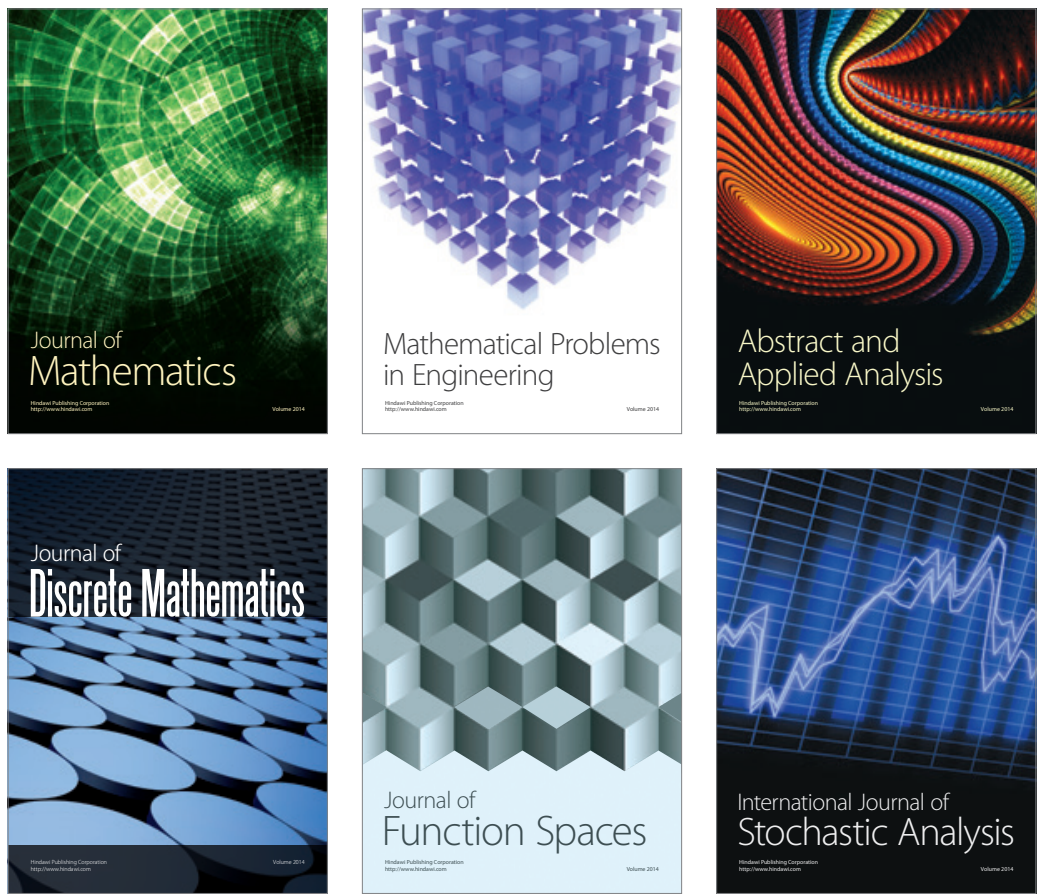

Journal of

Function Spaces

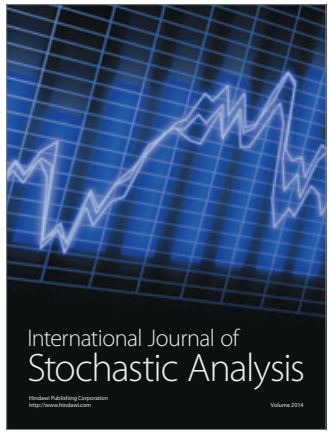

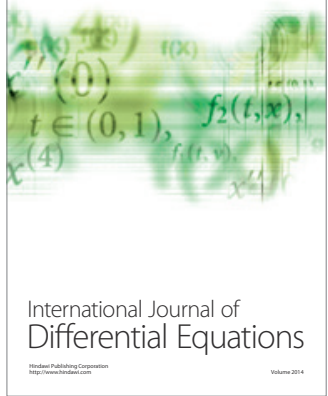
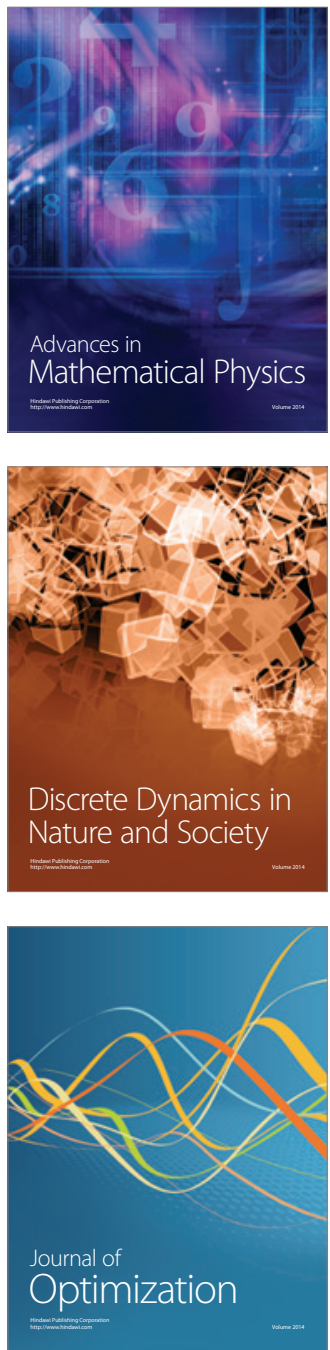